\title{
Erratum to: William Phelan. 2015. In place of inter-state retaliation: The European Union's rejection of WTO-style trade sanctions (Oxford: Oxford University Press)
}

\author{
Karen J. Alter ${ }^{1}$
}

Published online: 27 February 2016

(C) Springer Science+Business Media New York 2016

\section{Erratum to: Rev Int Organ (2016) 11:145-149 \\ DOI 10.1007/s11558-015-9232-x}

The original version of this article unfortunately contained a mistake. The name of "William Phelan" has been misspelled. William Phelen should be William Phelan in the title and all occurrences in the text.

The authors and editors regret the oversight.

The online version of the original article can be found at http://dx.doi.org/10.1007/s11558-015-9232-x.

Karen J. Alter

kalter@northwestern.edu

1 Northwestern University, Evanston, USA 